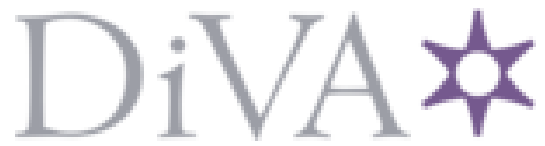

http://www.diva-portal.org

This is the published version of a paper published in Journalism Practice.

Citation for the original published paper (version of record):

Appelgren, E. (2019)

Remaining in Control with an Illusion of Interactivity: The Paternalistic Side of Data

Journalism*

Journalism Practice, (8): 956-960

https://doi.org/10.1080/17512786.2019.1642128

Access to the published version may require subscription.

N.B. When citing this work, cite the original published paper.

This is an Open Access article distributed under the terms of the Creative Commons Attribution-NonCommercial-NoDerivatives License (http://creativecommons.org/licenses/ by-nc-nd/4.o/), which permits non-commercial re-use, distribution, and reproduction in any medium, provided the original work is properly cited, and is not altered, transformed, or built upon in any way.

Permanent link to this version:

http://urn.kb.se/resolve?urn=urn:nbn:se:sh:diva-3876o 


\section{Remaining in Control with an Illusion of Interactivity: The Paternalistic Side of Data Journalism}

\section{Ester Appelgren}

To cite this article: Ester Appelgren (2019) Remaining in Control with an Illusion of Interactivity: The Paternalistic Side of Data Journalism, Journalism Practice, 13:8, 956-960, DOI: 10.1080/17512786.2019.1642128

To link to this article: https://doi.org/10.1080/17512786.2019.1642128

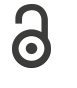

(C) 2019 The Author(s). Published by Informa

UK Limited, trading as Taylor \& Francis Group

曲 Published online: 19 Aug 2019.

Submit your article to this journal $\widetilde{1}$

Q View related articles $\sqsubset$

View Crossmark data \lceil 


\title{
Remaining in Control with an Illusion of Interactivity: The Paternalistic Side of Data Journalism*
}

\author{
Ester Appelgren
}

School of Natural Science, Technology and Environmental Studies, Södertörn University, Huddinge, Sweden

KEYWORDS Data journalism; paternalism; interactivity; visualization; control

\section{Culture Clash}

An inherent part of journalism is to select and filter, thus making decisions in the interests of the audience. Because the decisions result in a story, the choices made by the journalist are central, and they are accepted. Similar behavior conducted by an engineer, however, is often considered negative. This is because the technology design might limit individual autonomy. Facebook is a popular example of how technologists created algorithms that were able to exclude or emphasize content. The developers behind the algorithms may have created them with good intentions, but the paternalistic act of selecting and filtering in this particular context has been publicly questioned. However, the power to make filtering decisions on behalf of the audience is still a justified practice for journalists and a prerequisite for telling a story. The implication is that problems only arise if the audience cannot see the difference between the filtering and selection in various digital contexts. This is particularly interesting in data journalism, since it can be viewed as a convergence between the journalistic and the technological practice. Can data journalists still take the right to choose for the audience for granted, or does it now need to be earned?

News angles in data journalism stories usually come to life with the aid of visualizations. While some stories are more interactive than others, relationships and patterns in the data are explained using digital media. In this article, I try to address the intersection between investigative journalism and technological working methods in terms of the decisions made for and in the interests of the audience. I base my analysis on a review of data journalism published in the Nordic countries. In the Nordics, data journalism has flourished, much due to legislation that has existed for centuries regulating the freedom of information (Appelgren and Salaverría 2018), the close relationship between journalists and the open data movement (Aitamurto, Sirkkunen, and Lehtonen 2011) and the introduction of the European PSI Directive in 2003 (Appelgren and Nygren 2014). In cooperation with the open data movement, data journalists initially created projects that had a high level of 
interactivity. This allowed audiences to create and find their own story in the data. Baack (2015) explains that the influence from open data activists in terms of values is rooted in the hacking culture, where the ideology initially revolved around access to computer technology and free, decentralized information. Bradshaw (2014) argues that hackers embrace a culture of sharing, openness, and decentralization and want to make the world a better place. On a similar note, according to Kovach and Rosenstiel $(2014,9)$, the purpose of journalism is to provide people with the information they need to be free and self-governing. However, in contrast to the hackers' approach to decentralizing information, one element of journalistic work is to be in control of the information flow despite the distribution of control elements to the audience through multimedia and interactivity (Robinson 2007).

In data journalism, these two conflicting control ideals co-exist, much because of that in the context of data journalism visualizations, journalistic news angles are often, but not always, supported by interactivity. Recently, however, data journalists have become rather reluctant to use interactivity (Anderson and Borges-Rey 2019). Once a positive ideal and enabler for journalism, interactive features have somewhat dropped in status.

\section{Paternalism, for Better or Worse}

Researchers have associated paternalism in technological design with autonomy and control. One popular example is self-driving cars, where automated decision-making could have a potentially devastating effect on individuals (Spiekermann and Pallas 2006 , 8). The fear is related to a perceived lack of control; machines are entrusted to make decisions for humans in order to simplify a given situation. Self-driving cars can slow a speeding driver, even though there might be a reason for why the driver is speeding. Thus, the act becomes a punishment. In journalism, an example of paternalistic punishment is filter bubbles. When a person enters a website with personalization features that stores cookies on the computer to link users with their media consumption history, the system can make decisions based on this person's interests. Sometimes, the system draws on data about previous reading habits to determine which stories to display without the person's active consent. As a result, some stories may be excluded. The person obviously misses out on some of the content, even though the selected content might be perceived as highly relevant.

Designers can also "nudge" people into making a desired selection (Thaler, Sunstein, and Balz 2013). No coercion is involved in nudging; rather, the goal is to influence people to make choices that make them better off (Thaler and Sunstein 2003). This positive view of paternalism is not associated with control, but rather the ability to choose through design and contribute to welfare. In this context, journalists act as public-spirited choice architects, nudging people in directions they might not have specifically chosen in advance, thus aiming to help them make better decisions later (Thaler, Sunstein, and Balz 2013, 437). However, even though nudging will guide individuals to different options, this act should not forbid the possibility of making other choices (Mirsch, Lehrer, and Jung 2017). Thus, linear and pre-packaged content flow might not be an example of nudging, while a project with an interactive storyline is. The data set or methodology behind the investigation might also be transparent enough for the audience to be in control of the presented information and its accuracy. 


\section{Examples of Paternalism Found in Nordic Data Journalism Projects}

Given the high level of technological features in data journalism, we cannot take for granted that data journalism will always be protected from the negative interpretation of technology paternalism by the audience. Therefore, I explored the visual elements used for paternalistic decisions in 31 data journalistic projects submitted to the NODA Awards (Nordic Data Journalism Awards) in 2013, 2015 and 2016, and I found that three elements were primarily used in a paternalistic manner.

\section{- Scroll}

The scroll function often triggers the start of an element without the user actively clicking on it, e.g., a video clip that starts playing when the user scrolls past it. These projects typically consist of a linear flow with interactive elements. The choices are limited, and the story moves forward as the audience member scrolls. Nevertheless, the projects were rich in sound clips, moving images, maps and diagrams, but rarely with possibilities to navigate within the content.

- Videos showing interactivity

Visualizing graphics in the form of a video, or more specifically in videos of interactive maps, were considered paternalistic when they showed the perspective of another user surfing the website, interacting with an interactive graph or clicking on links. This prerecorded perspective gives the user the illusion of interactivity and being in control.

- Personalization

Related to an unexpected change in the website appearance or functionality as the user interacts with the content, personalization is an indicator of technological paternalism since it is presumed to be in the interest of the individual, yet it is set in motion by preprogrammed algorithms without the user's active consent.

In 2013, a typical data journalistic project nominated for the Nordic Data Journalism Awards consisted of data in a database that had been refined and filtered by journalists and developers. There were often simplified interactive possibilities for the audience to further filter data and visualizations.

In 2015, interactivity was less common. Instead, large projects were often developed primarily for cell phones and based on advanced investigative reporting methods. These projects were often published as stand-alone websites, separate from the main newspaper or broadcasting company. There were many choices for the audience to explore the story in the form of portraits, supporting news angles and sometimes interactive elements. It was common to find a link to a specific page explaining the journalistic methodology, but several projects lacked a description of methodology and a clear sender.

In 2016, the long-read format dominated the sample. Stories were dramatic and contained strong imagery. However, such stories were occasionally found before 2016, for example the 10th anniversary of the Estonia catastrophe, when a cruise ship sunk in the Baltic Sea and hundreds of passengers lost their lives. Another example was a diving expedition in a Norwegian mountain that went wrong. If the audience member scrolled through the project, there were no possibilities of avoiding the strong images; there was a low level of control and the scroll function was the only way to move forward. 


\section{Paternalism and the Linear Pre-Packaged Story}

In the two examples of strong content mentioned above, it is worth considering the limit for when it is in the interest of the audience to make paternalistic decisions through the scroll function, but also what preunderstanding the audience have of journalism and how it may be affected by the paternalistic design choices. I also found that there were a few projects in the sample where a user was filmed while interacting with a website. This creates an illusion of interactivity, but in reality, the flow is completely linear and prepackaged.

More recently, media companies are finding linear storytelling formats to be more successful than truly interactive and less paternalistic data journalism projects. Paternalism is thus probably preferable from a commercial perspective in terms of making the audience stay longer.

Researchers consider journalistic paternalism important for maintaining journalistic autonomy. At the same time, in the public debate, and on the very same technological platforms, filter bubbles and the danger of entrusting decisions to machines are considered to be negative paternalism, as long as it does not involve the journalistic context.

In an age when journalism is merging with artificial intelligence, and journalists and engineers are creating algorithms alongside one another, can this form of automated journalistic decision-making be considered justified and in the interest of the audience member? To protect their immunity, journalists thus need to make sure that the audience is informed about the methodology and that the design choices found in interactive projects like data journalism are clearly motivated and explained.

\section{Disclosure Statement}

No potential conflict of interest was reported by the author.

\section{ORCID}

Ester Appelgren (1D http://orcid.org/0000-0003-1428-9477

\section{References}

Aitamurto, Tanja, Esa Sirkkunen, and Pauliina Lehtonen. 2011. Trends in Data Journalism. Next Media Hyperlocal. Espoo: VTT.

Anderson, B., and E. Borges-Rey. 2019. "Encoding the UX: User Interface as a Site of Encounter between Data Journalists and Their Constructed Audiences." Digital Journalism 1-17. doi:10. 1080/21670811.2019.1607520

Appelgren, Ester, and Gunnar Nygren. 2014. "Data Journalism in Sweden: Introducing New Methods and Genres of Journalism into 'Old' Organizations." Digital Journalism 2 (3): 394-405.

Appelgren, E., and R. Salaverría. 2018. "The Promise of the Transparency Culture: A Comparative Study of Access to Public Data in Spanish and Swedish Newsrooms." Journalism Practice 12 (8): 986-996.

Baack, Stefan. 2015. "Datafication and Empowerment: How the Open Data Movement Re-Articulates Notions of Democracy, Participation, and Journalism." Big Data \& Society 2 (2): 1-11.

Bradshaw, Paul. 2014. "What is Data Journalism." In Ethics for Digital Journalists: Emerging Best Practices, edited by Zion Lawrie and David Craig, 202-219. New York: Routledge. 
Kovach, Bill, and Tom Rosenstiel. 2014. The Elements of Journalism: What Newspeople Should Know and the Public Should Expect. New York: Three Rivers Press.

Mirsch, Tobias, Christiane Lehrer, and Reinhard Jung. 2017. "Digital Nudging: Altering User Behavior in Digital Environments." In Proceedings der 13. Internationalen Tagung Wirtschaftsinformatik (WI 2017), (Hrsg.) J. M. Leimeister and W. Brenner, 634-648. St. Gallen, S.

Robinson, Sue. 2007. "Someone's Gotta Be in Control Here. The Institutionalization of Online News and the Creation of a Shared Journalistic Authority." Journalism Practice 1 (3): 305-321.

Spiekermann, Sarah, and Frank Pallas. 2006. "Technology Paternalism-Wider Implications of Ubiquitous Computing." Poiesis \& Praxis 4 (1): 6-18.

Thaler, Richard H., and Cass R. Sunstein. 2003. "Libertarian Paternalism." The American Economic Review 93 (2): 175-179.

Thaler, Richard H., Cass R. Sunstein, and John P. Balz. 2013. "Choice Architecture." In The Behavioral Foundations of Public Policy, edited by E. Shafir, 428-439. Princeton: Princeton University Press. 